\title{
Evaluating the Efficiencies and Developing Ways of Better Energy Management of Wood Stoves
}

\author{
Krishnam Nair,", Rishal Amar Singh ${ }^{2}$ \\ ${ }^{1}$ School of Engineering and Physics, Faculty of Science, Technology and Environment, The University of the South Pacific, Fiji \\ ${ }^{2}$ College of Engineering, Science and Technology, Fiji National University, Fiji
}

Copyright (C) 2015 Horizon Research Publishing All rights reserved.

\begin{abstract}
The fuelwood characteristics of ten different tree species have been investigated. The species investigated were Mango (Mangifera Indica) ,Tamarind (Tamarindus Indica), Raintree (Samanea Saman),Javaplum/ Jamun (Syzygium Jambolanum),Margosa / Neem (Azadirachta Indica ),Lemon tree (Citrus Limonia),Pine tree (Pinus Caribaea)Black Mangrove / Tiri-tiri (Bruguieria Gymnohiza), Guava (Psidium Guajava), and Australian Pine / Jhau (Casuarinaceae Casuarina Equisetifolia L.). The properties examined were their moisture content and how it varied over a period of 'drying time', calorific value and its dependency on the moisture content, and their emissions and efficiency when burnt in a miniature rocket stove.
\end{abstract}

Keywords Calorific Value, Moisture Content, Miniature Rocket Stove

\section{Introduction}

There has been much focus into conservation of energy for the past decade as our fossil fuel reserves diminish with demand for new and better standards of living pushing to all-time highs. Conservation may be achieved through efficient energy use, in which case energy use is decreased while achieving a similar outcome, or by reduced consumption of energy services.

An example of such conservation can be directed to our cooking methods and techniques. It was revealed in the national 2007 census that 42 percent of Fiji's population use traditional wood stoves for cooking purposes [1]. On a global perspective traditional biomass is still the largest form of renewable energy used. Renewable energy sources present $19 \%$ of our global energy demand out of which $3.8 \%$ is made up of hydropower and $2 \%$ is from wind, solar, geothermal, biomass and biofuel [2].

Therefore it would be just and appropriate to design better and efficient stoves without doing overhaul changes to existing stove structures. This may only be possible with study of the existing systems and to be able to account for the heat losses from the respective systems so as to find ways of minimizing these losses. Needless to say, the efficiency of a wood stove depends strongly on the type of fuelwood used so studying and determining the characteristics of locally available woods is a must in order to curb this quandary of inefficient and costly cooking systems. Efficient stoves also mean less green-house gas emissions which in turns reduce effects and risks of health and climatic hazards. This is due to the fact that in efficient stoves the smoke itself is burned within the stove, giving off little more than a transparent vapor resulting in better efficiency and greater heat output from the same amount of wood.

This paper attempts to identify species that can be best used as fuelwood based on their calorific values, moisture contents as a function of drying time, emissions and efficiency when burnt as fuel for cooking.

\section{Materials and Methods}

The wood samples used for this project were Mango (Mangifera Indica), Tamarind (TamarindusIndica),

Raintree (Samanea Saman),Javaplum/ Jamun (Syzygium Jambolanum), Margosa / Neem (Azadirachta Indica),Lemon tree (Citrus Limonia), Pine tree (Pinus Caribaea)Black Mangrove / Tiri-tiri (Bruguieria Gymnohiza), Guava (Psidium Guajava), and Australian Pine / Jhau (Casuarinaceae Casuarina Equisetifolia L.).Fresh wood lengths were obtained from Nawai Settlement in Sigatoka.

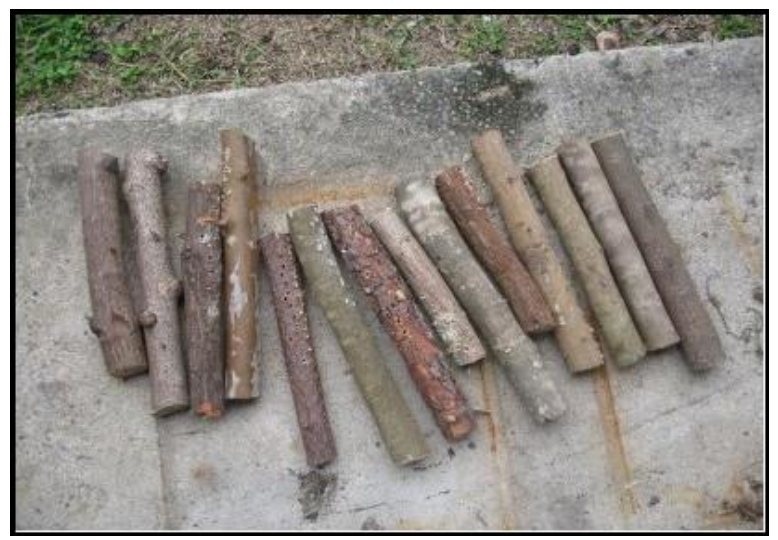

Figure 1. Freshly harvested woods 
Each length of wood was divided into 8 equal lengths. This was done so that the rate of drying is fairly constant in all the pieces. One portion was used as control (to find Moisture Content weekly). The other pieces were kept to obtain samples for calorific value and stove efficiency determination. After initial measurements for energy content, moisture content, density the samples were subjected to sun drying for a period of 7 days before the measurements were repeated. This sequence was repeated for the next 7 weeks. The fuel efficiency and the emission levels were also determined for these weeks.

\subsection{Procedure for Determining Calorofic Value / Energy Content}

The Energy Contents of the samples were obtained using a Ballistic Bomb Calorimeter. The sample is ignited by sending a small electrical current through a wire that ignites a cotton fuse, which in turn ignites the fuel sample. A thermocouple senses the increase in temperature from the burning sample, which is measured by a sensitive galvanometer [3].

To standardize the apparatus, a correction for constant heat gain and calibrating with a standard sample was performed. Correction for constant heat gain needed to be done because during every test a small constant amount of heat was released in the bomb by the firing current and cotton. In order to measure this heat, a test was carried out in the standard manner but without any sample in the crucible. The deflection on the galvanometer was noted over approximately 40 seconds. This value was subtracted from all the galvanometer readings of various wood samples. Calibration with standard sample was necessary as this established the relationship between the galvanometer deflection and the amount of heat released by the combustion of the sample. This test was carried out in the standard manner using benzoic acid whose calorific value is 26.44 $\mathrm{kJ} / \mathrm{g}$ [3].

The wood lengths were drilled to obtain its sawdust and this was placed in the crucible in mass range of 0.4 to $0.6 \mathrm{~g}$. This mass was chosen so as to ensure that the galvanometer reading did not go beyond the full scale deflection value. The sample and the crucible were then placed in the support pillar with a $5 \mathrm{~cm}$ length of cotton thread. One end of the thread was tied to the firing wire and the other end was gently placed amongst the sawdust inside the crucible. The chamber was then closed, oxygen of about 25atm was supplied and the thermocouple was plugged on top of the bomb body. The fire button initiated the combustion process and the amount of heat released was indicted by the deflection of the galvanometer. In order to achieve precision, three tests were done using each type of wood [3].

\subsection{Moisture Content Analysis}

The Moisture Content was determined by having a control wood in the experiment. The M.C was calculated by the following formulas;

$$
\begin{gathered}
\text { Wet Basis Moisture Content. } \\
\mathrm{M} . \mathrm{C}=\left(\mathrm{m}_{\mathrm{f}}-\mathrm{m}_{\mathrm{o}}\right) / \mathrm{m}_{\mathrm{f}} \times 100 \% \\
\text { Dry Basis Moisture Content } \\
\text { M.C }=\left(\mathrm{m}_{\mathrm{f}}-\mathrm{m}_{\mathrm{o}}\right) / \mathrm{m}_{\mathrm{o}} \times \quad \times \quad 100 \%
\end{gathered}
$$

where $\mathrm{m}_{\mathrm{f}}$ is the final mass after dehydration and $\mathrm{m}_{\mathrm{o}}$ is the initial mass with maximum moisture. Moisture content of the green wood was determined by weighing the sample on an analytical balance and recording the mass as $\mathrm{m}_{\mathrm{o}}$ and then drying the sample in an oven at a temperature of $105^{\circ} \mathrm{C}$ for 24 hours. The oven dried mass was determined and recorded as $m_{f}$. For weeks proceeding, the mass of the control wood on the preceding week was taken to be $\mathrm{m}_{\mathrm{o}}$ and the mass on the measuring week to be $\mathrm{m}_{\mathrm{f}}[4]$.

\subsection{Procedure for Determining Density}

Density was determined by weighing the control sample directly on an analytical balance and by calculating the volume. To do this, it was assumed that the wood pieces were regular cylinders. Once the mass and the volume were established, the density was calculated by dividing the mass of the wood by its volume [5].

\subsection{Calculation of Fuelwood Efficiency}

A significant way to improve the fuel efficiency of stoves is to improve the heat transfer from the fire to the cooking vessel. Most importantly, the hot air and gas released from the fire must contact the cooking vessel over the largest possible surface area. This is accomplished through the use of a pot skirt that creates a narrow channel forcing hot air and gas to flow along the bottom and sides of the cooking vessel. A miniature stove was designed emulate this concept. This stove was used to determine the efficiency of the fuelwoods when combusted.

The efficiency of a combustion system can be determined by using the heat produced in that system to heat a known amount of water. The efficiency of the stove, $\eta$, may be defined as the heat gained by the water and the pot divided by the heat supplied by the burning fuel. This heat supplied by the fuel can be assumed to be the energy content of the respective fuel given the fuel completely burns off without residue. Heat gained by the water and pot can be calculated using simple calorimetry, $\mathrm{H}=\mathrm{mc} \Delta \mathrm{T}$ where $\mathrm{m}$ is the mass of the water, $\mathrm{c}$ is the specific heat capacity and $\Delta \mathrm{T}$ is the temperature change of water in the pot. This heat supplied by the fuel can be assumed to be the energy content of the respective fuel (its calorific value) given the fuel completely burns off without residue. 


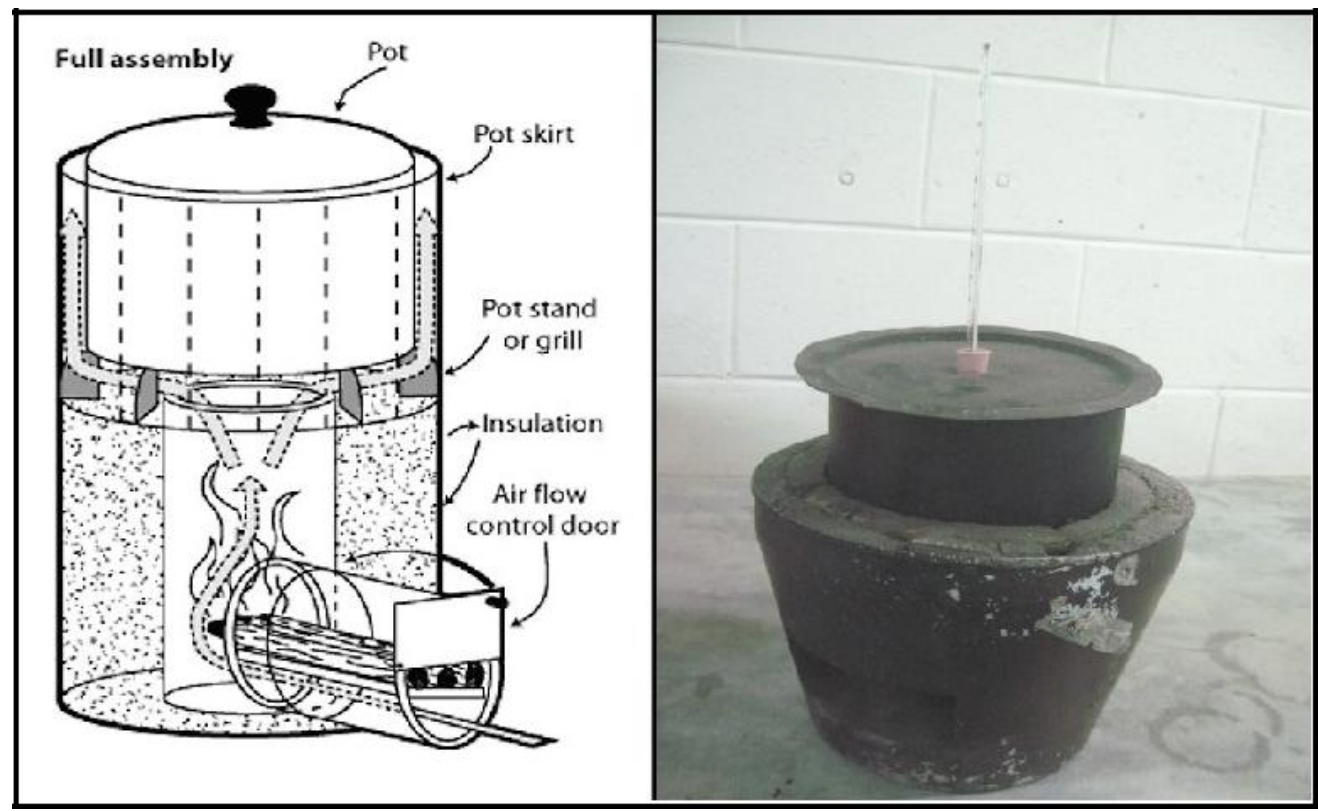

Figure 2. Theoretical and experimental setup

\subsection{Determining Emission Levels}

The Horiba PG-250 setup is used to determine the emission levels which are produced in the studied combustion system. The PG-250 is a portable stack gas analyzer that simultaneously measures five separate gas components. The instrument uses non-dispersive IR detection for $\mathrm{CO}, \mathrm{SO}_{2}$ and $\mathrm{CO}_{2}$; a cross flow modulation for $\mathrm{NO}_{2}$, and a zirconium oxide sensor for $\mathrm{O}_{2}$ measurements.

The inlet consists of a suction tube and this tube was inserted in the stove via a metal connection. The flow rate was maintained at $0.51 / \mathrm{min}$.

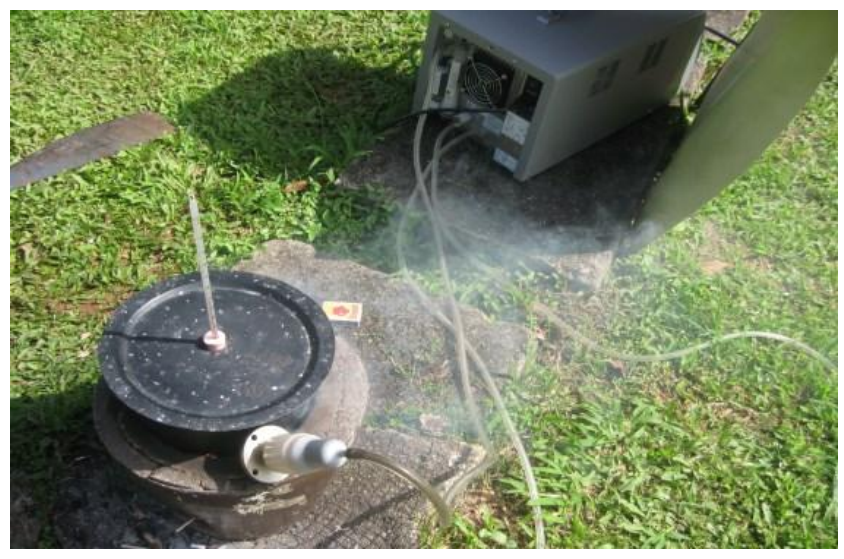

Figure 3. Horiba Setup measuring emission levels.

\subsection{Heat Losses}

The heat losses from the combustion system are;

- Evaporative Heat Loss

- Heat gained by stove

- conductive heat loss

- irradiative heat loss
- convective heat loss

For further design improvements on the stove the above quantities were calculated and analyzed for one week of combustion measurements. The final week was chosen because fuelwoods are practically burnt after several weeks of drying and when they have minimal moisture contents.

\subsection{Evaporative Heat Loss}

Evaporative heat loss is calculated by the multiplying the mass of the water evaporated in the system by the Latent Heat of Vaporization of water.

\subsection{Heat Gained By Stove}

This loss of energy is determined by calorimetry,

$\mathrm{H}=\mathrm{mc} \Delta \mathrm{T}$ where $\mathrm{m}$ is the mass of the stove, $\mathrm{c}$ is the specific heat capacity of the material (concrete) and $\Delta \mathrm{T}$ is the temperature change of stove.

\subsection{Conductive Heat Loss}

The conductive heat loss is the heat loss through conduction and it is highly dependent on the thermal conductivity of the conducting material.

The stove is considered to be a hollow cylinder with an inner and outer radius, $r_{1}$ and $r_{2}$. Heat loss through a hollow cylinder is given by;

$$
\mathrm{G}=\frac{\mathrm{k}^{\prime}\left(\mathrm{T}_{1}-\mathrm{T}_{2}\right)}{\mathrm{r}_{2} \ln \left(\mathrm{r}_{2} / \mathrm{r}_{1}\right)}
$$

where $\mathrm{k}^{\prime}$ is the thermal conductivity of the material, $\mathrm{T}_{1}$ is the temperature of the heat emitter (in this case, the flame), and $\mathrm{T}_{2}$ is the temperature of the stove body. $\mathrm{T}_{1}$ and $\mathrm{T}_{2}$ were measured using thermocouples. 


\subsection{Irradiative Heat Loss}

The Stefan-Boltzmann's Law for a blackbody radiator is used to determine total heat loss via radiation.

If the hot object is radiating energy to its cooler surroundings at temperature $\mathrm{T}$, the net radiation loss rate takes the form

$\mathrm{R}=4 \delta \mathrm{T}^{3}\left(\mathrm{~T}_{\mathrm{s}}-\mathrm{T}\right)$ where $\mathrm{R}$ is the heat transfer rate, $\delta$ is the Stefan-Boltzmann constant, $\mathrm{T}$ is the ambient temperature and $\mathrm{T}_{\mathrm{S}}$ is the surface temperature of the blackbody.

Power radiated to atmosphere is determined by multiplying $\mathrm{R}$, the net radiation loss, with the surface area of the emitting body. Henceforth, energy lost is simply the power radiated multiplied by the radiation time.

\subsection{Convective Heat Loss}

The convective heat loss may be determined by considering the stove-pot to be a vertical cylinder and by using the equation; $\mathrm{C}=\mathrm{Nuk}\left(\mathrm{T}_{\mathrm{S}}-\mathrm{T}\right) / \mathrm{d}$ where $\mathrm{k}$ is the thermal conductivity of air, $\mathrm{T}_{\mathrm{S}}$ is the average surface temp. of pot/stove, $T$ is the air temperature and $\mathrm{d}$ is the diameter of cylinder. To determine $\mathrm{Nu}$, the Nusselt's number it is important to determine the dominating form of convection occurring. Free convection was studied. Free convection is whereby fluid motion by density gradients in the fluid when it is heated or cooled by the exchange surface [6].

\section{Results and Discussion}

The Figures 4 and 5 clearly reveal the relationship between the moisture content and drying time. It is noted that there is a sharp decrease in the moisture content levels for the first week of drying and that the M.C amounts then gradually decrease to a value around 2 to 5 percent and remains steady thereon. Pine is seen to have the highest wet basis moisture content of $62 \%$ and a dry basis moisture content of $170 \%$. Wood species which had considerably low moisture contents were Australian Pine, Tamarind and Margosa woods.

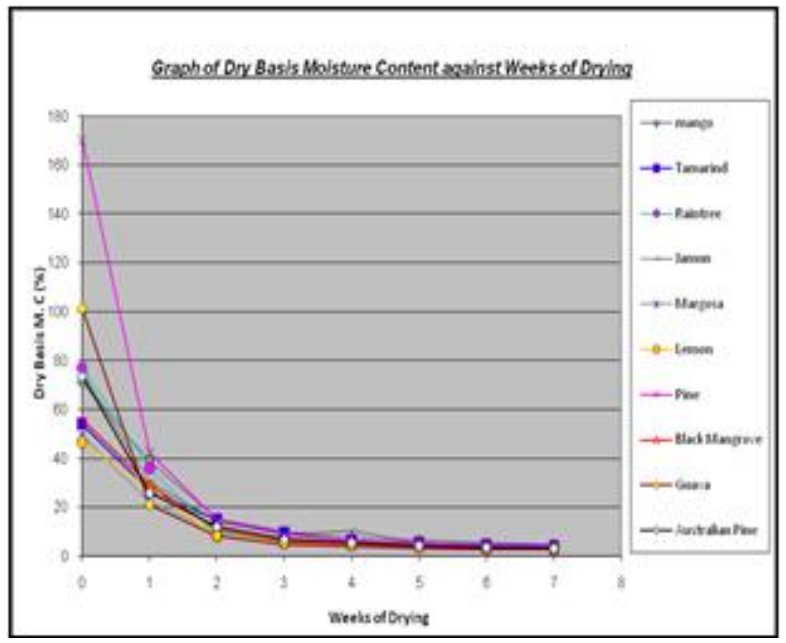

Figure 4. Dry Basis M. C against Weeks of Drying

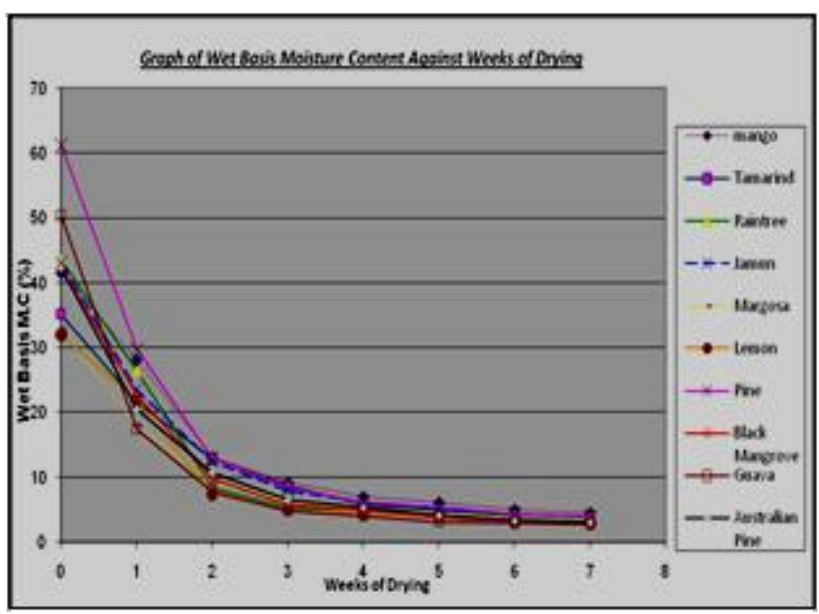

Figure 5. Wet Basis M.C against Weeks of Drying

Variations in the amount of moisture in different woods can be influenced by the climatic conditions, the host land's topography, time and season of year and the area of the stem where samples were taken and analyzed from Huhtinen [7]. Wood starts to dry as soon as it is cut. During the first stages as seen in Figure 4 and Figure 5 water will be lost rapidly until fibre saturation point of about $20 \%$ W.B moisture content. After this stage, drying slows down since it involves the removal of bound water. Drying beyond the fibre saturation point to equilibrium moisture content of about $10 \%$ takes quite a long time [6]. Factors that most probably determine the rate of moisture loss from these wood species are the surface area of wood exposed to sun, ambient temperature, humidity and amount of solar irradiation for the particular drying time.

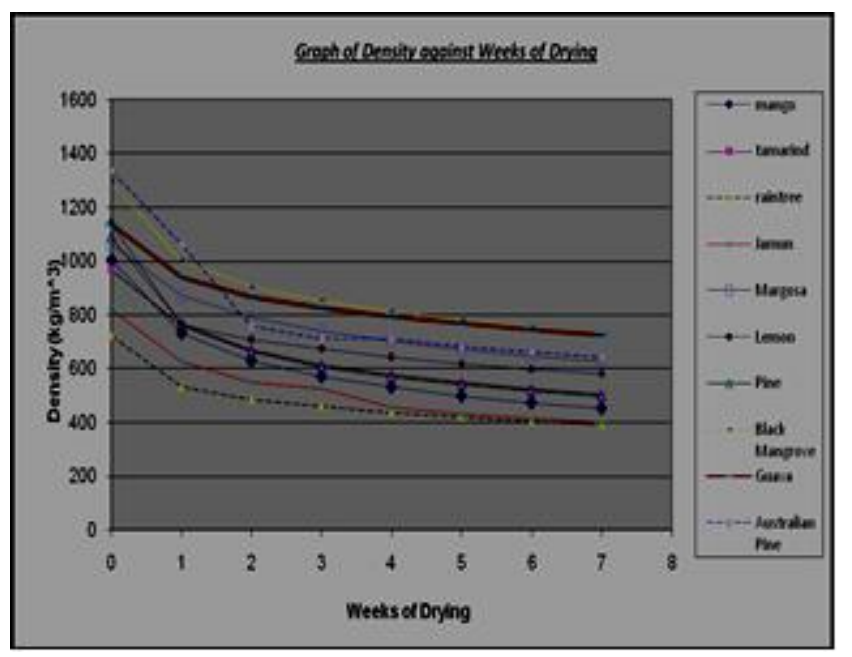

Figure 6 Density of woods against weeks of drying

Drying of wood tends to make wood stronger, weight is reduced [8]. Hence, it can be said that with increasing sun drying days, the density decreases as shown in Figure 6. Wood has water particles embossed in their grain structure and when these water particles evaporate, the mass decreases resulting in decreasing density. 
It is seen from Figure 7 that with increasing moisture contents, the calorific value of the wood species decreases. This is perhaps due to the fact that if moisture content is high then more energy is used up to get rid of the moisture and hence the calorific value decreases.

Table 1 reveals that at 7 weeks of drying time, Australian Pine had the highest calorific value of $36 \mathrm{MJ} / \mathrm{kg}$. Lemon, Black Mangrove and Guava followed with $32 \mathrm{MJ} / \mathrm{kg}$, $31 \mathrm{MJ} / \mathrm{kg}$ and $30 \mathrm{MJ} / \mathrm{kg}$ respectively. Raintree had the lowest calorific value of $23 \mathrm{MJ} / \mathrm{kg}$. Tables 2 and 3 indicate the various densities and the moisture contents of the sample as a function of drying time. Because of the various biological structures present in woods, particularly the location of xylem and phloem vessels, the energy content is expected to vary. Random sampling was therefore carried out to overcome this predicament.

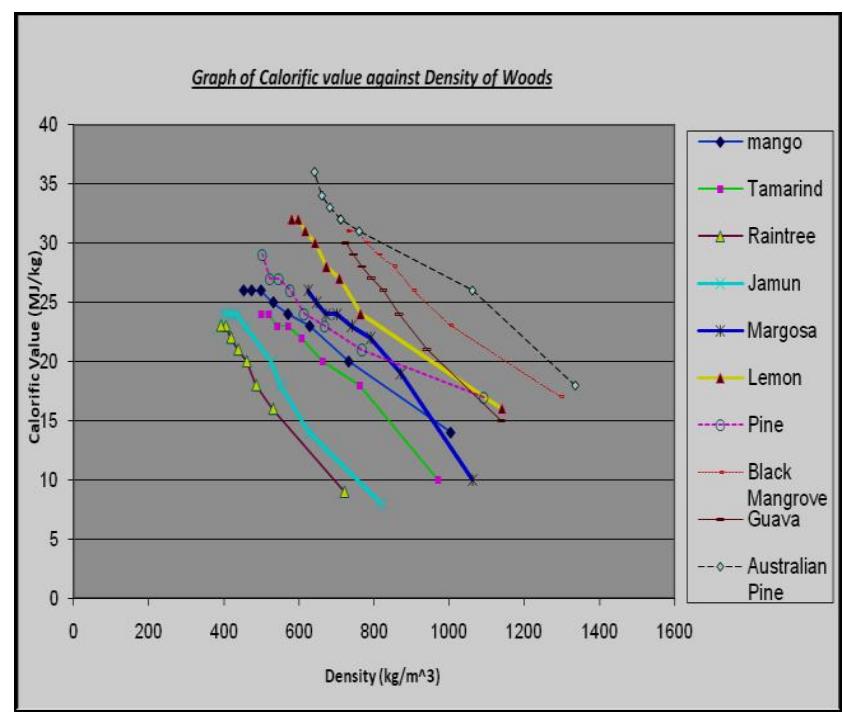

Figure 7. Calorific Value of Woods against Density.

Table 1. Moisture Content of woods

\begin{tabular}{|c|c|c|c|c|c|c|c|c|c|c|c|c|c|c|c|c|c|c|c|c|}
\hline \multirow{2}{*}{$\begin{array}{c}\text { Weeks of } \\
\text { Drying }\end{array}$} & \multicolumn{2}{|c|}{ Mango } & \multicolumn{2}{|c|}{ Tamarind } & \multicolumn{2}{|c|}{ Raintree } & \multicolumn{2}{|c|}{ Jamun } & \multicolumn{2}{|c|}{ Margosa } & \multicolumn{2}{|c|}{ Lemon } & \multicolumn{2}{|c|}{ Pine } & \multicolumn{2}{|c|}{$\begin{array}{c}\text { Black } \\
\text { Mangrove }\end{array}$} & \multicolumn{2}{|c|}{ Guava } & \multicolumn{2}{|c|}{$\begin{array}{l}\text { Australian } \\
\text { Pine }\end{array}$} \\
\hline & $\begin{array}{l}\text { WET } \\
(\%)\end{array}$ & $\begin{array}{c}\text { DRY } \\
(\%)\end{array}$ & $\begin{array}{l}\text { WET } \\
(\%)\end{array}$ & $\begin{array}{c}\text { DRY } \\
(\%)\end{array}$ & $\begin{array}{l}\text { WET } \\
(\%)\end{array}$ & $\begin{array}{c}\text { DRY } \\
(\%)\end{array}$ & $\begin{array}{l}\text { WET } \\
(\%)\end{array}$ & $\begin{array}{l}\text { DRY } \\
(\%)\end{array}$ & $\begin{array}{c}\text { WET } \\
(\%)\end{array}$ & $\begin{array}{c}\text { DRY } \\
(\%)\end{array}$ & $\begin{array}{l}\text { WET } \\
(\%)\end{array}$ & $\begin{array}{c}\text { DRY } \\
(\%)\end{array}$ & $\begin{array}{c}\text { WET } \\
(\%)\end{array}$ & $\begin{array}{c}\text { DRY } \\
(\%)\end{array}$ & $\begin{array}{c}\text { WET } \\
(\%)\end{array}$ & $\begin{array}{c}\text { DRY } \\
(\%)\end{array}$ & $\begin{array}{c}\text { WET } \\
(\%)\end{array}$ & $\begin{array}{c}\text { DRY } \\
(\%)\end{array}$ & $\begin{array}{l}\text { WET } \\
(\%)\end{array}$ & $\begin{array}{c}\text { DRY } \\
(\%)\end{array}$ \\
\hline 0 & $\begin{array}{c}41.5 \\
\pm \\
0.7\end{array}$ & $\begin{array}{c}70.9 \\
\pm \\
0.7\end{array}$ & $\begin{array}{c}35.1 \\
\pm \\
0.6\end{array}$ & $\begin{array}{c}54.1 \\
\pm \\
0.6\end{array}$ & $\begin{array}{c}43.5 \\
\pm \\
0.6\end{array}$ & $\begin{array}{c}77.0 \\
\pm \\
0.6\end{array}$ & $\begin{array}{c}43.1 \\
\pm \\
0.7\end{array}$ & $\begin{array}{c}75.6 \\
\pm \\
0.7\end{array}$ & $\begin{array}{c}33.0 \\
\pm \\
0.5\end{array}$ & $\begin{array}{c}49.2 \\
\pm \\
0.5\end{array}$ & $\begin{array}{c}32.0 \\
\pm \\
0.5\end{array}$ & $\begin{array}{c}46.6 \\
\pm \\
0.5\end{array}$ & $\begin{array}{c}61.2 \\
\pm \\
0.8\end{array}$ & $\begin{array}{c}170.1 \\
\pm \\
0.8\end{array}$ & $\begin{array}{c}42.2 \\
\pm \\
0.6\end{array}$ & $\begin{array}{c}55.7 \\
\pm \\
0.6\end{array}$ & $\begin{array}{c}50.3 \\
\pm \\
0.5\end{array}$ & $\begin{array}{c}101.4 \\
\pm \\
0.5\end{array}$ & $\begin{array}{c}42.3 \\
\pm \\
0.6\end{array}$ & $\begin{array}{c}73.5 \\
\pm \\
0.6\end{array}$ \\
\hline 1 & $\begin{array}{c}28.1 \\
\pm \\
0.5\end{array}$ & $\begin{array}{c}38.9 \\
\pm \\
0.5\end{array}$ & $\begin{array}{c}21.5 \\
\pm \\
0.5\end{array}$ & $\begin{array}{c}27.4 \\
\pm \\
0.5\end{array}$ & $\begin{array}{c}26.4 \\
\pm \\
0.4\end{array}$ & $\begin{array}{c}35.9 \\
\pm \\
0.4\end{array}$ & $\begin{array}{c}23.4 \\
\pm \\
0.3\end{array}$ & $\begin{array}{c}30.5 \\
\pm \\
0.3\end{array}$ & $\begin{array}{c}18.0 \\
\pm \\
0.4\end{array}$ & $\begin{array}{c}21.9 \\
\pm \\
0.4\end{array}$ & $\begin{array}{c}21.8 \\
\pm \\
0.5\end{array}$ & $\begin{array}{c}27.9 \\
\pm \\
0.5\end{array}$ & $\begin{array}{c}29.7 \\
\pm \\
0.5\end{array}$ & $\begin{array}{c}42.2 \\
\pm \\
0.5\end{array}$ & $\begin{array}{c}22.6 \\
\pm \\
0.4\end{array}$ & $\begin{array}{c}29.2 \\
\pm \\
0.4\end{array}$ & $\begin{array}{c}17.4 \\
\pm \\
0.3\end{array}$ & \begin{tabular}{|c|}
21.1 \\
\pm \\
0.3
\end{tabular} & $\begin{array}{c}20.5 \\
\pm \\
0.4\end{array}$ & $\begin{array}{c}25.8 \\
\pm \\
0.4\end{array}$ \\
\hline 2 & $\begin{array}{c}13.1 \\
\pm \\
0.4\end{array}$ & $\begin{array}{c}15.1 \\
\pm \\
0.4\end{array}$ & $\begin{array}{c}12.9 \\
\pm \\
0.3\end{array}$ & $\begin{array}{c}14.9 \\
\pm \\
0.3\end{array}$ & $\begin{array}{c}8.4 \\
\pm \\
0.3\end{array}$ & $\begin{array}{c}9.2 \\
\pm \\
0.3\end{array}$ & $\begin{array}{c}12.4 \\
\pm \\
0.3\end{array}$ & $\begin{array}{c}14.2 \\
\pm \\
0.3\end{array}$ & $\begin{array}{c}9.2 \\
\pm \\
0.5\end{array}$ & $\begin{array}{c}10.1 \\
\pm \\
0.5\end{array}$ & $\begin{array}{c}7.4 \\
\pm \\
0.4\end{array}$ & $\begin{array}{c}7.9 \\
\pm \\
0.4\end{array}$ & $\begin{array}{c}12.8 \\
\pm \\
0.5\end{array}$ & $\begin{array}{c}14.7 \\
\pm \\
0.5\end{array}$ & $\begin{array}{c}9.7 \\
\pm \\
0.3\end{array}$ & $\begin{array}{c}11.0 \\
\pm \\
0.3\end{array}$ & $\begin{array}{c}7.8 \\
\pm \\
0.4\end{array}$ & $\begin{array}{c}8.5 \\
\pm \\
0.4\end{array}$ & $\begin{array}{c}10.7 \\
\pm \\
0.3\end{array}$ & $\begin{array}{c}12.0 \\
\pm \\
0.3\end{array}$ \\
\hline 3 & $\begin{array}{c}9.2 \\
\pm \\
0.3\end{array}$ & $\begin{array}{c}10.1 \\
\pm \\
0.3\end{array}$ & $\begin{array}{c}8.6 \\
\pm \\
0.3\end{array}$ & $\begin{array}{c}9.4 \\
\pm \\
0.3\end{array}$ & $\begin{array}{c}5.2 \\
\pm \\
0.3\end{array}$ & $\begin{array}{c}5.5 \\
\pm \\
0.3\end{array}$ & $\begin{array}{c}7.9 \\
\pm \\
0.3\end{array}$ & $\begin{array}{c}8.6 \\
\pm \\
0.3\end{array}$ & $\begin{array}{c}6.3 \\
\pm \\
0.3\end{array}$ & $\begin{array}{c}6.7 \\
\pm \\
0.3\end{array}$ & $\begin{array}{c}5.0 \\
\pm \\
0.3\end{array}$ & $\begin{array}{c}5.3 \\
\pm \\
0.3\end{array}$ & $\begin{array}{c}8.3 \\
\pm \\
0.3\end{array}$ & $\begin{array}{c}9.1 \\
\pm \\
0.3\end{array}$ & $\begin{array}{c}5.6 \\
\pm \\
0.3\end{array}$ & $\begin{array}{c}5.9 \\
\pm \\
0.3\end{array}$ & $\begin{array}{c}4.8 \\
\pm \\
0.3\end{array}$ & $\begin{array}{c}5.0 \\
\pm \\
0.3\end{array}$ & $\begin{array}{c}6.4 \\
\pm \\
0.3\end{array}$ & $\begin{array}{c}6.8 \\
\pm \\
0.3\end{array}$ \\
\hline 4 & $\begin{array}{c}7.0 \\
\pm \\
0.6 \\
\end{array}$ & $\begin{array}{c}7.5 \\
\pm \\
0.6 \\
\end{array}$ & $\begin{array}{c}5.8 \\
\pm \\
0.5 \\
\end{array}$ & $\begin{array}{c}6.2 \\
\pm \\
0.5 \\
\end{array}$ & $\begin{array}{c}5.0 \\
\pm \\
0.4 \\
\end{array}$ & $\begin{array}{c}5.3 \\
\pm \\
0.4 \\
\end{array}$ & $\begin{array}{c}6.2 \\
\pm \\
0.5\end{array}$ & $\begin{array}{c}10.3 \\
\pm \\
0.5 \\
\end{array}$ & $\begin{array}{c}5.3 \\
\pm \\
0.3 \\
\end{array}$ & $\begin{array}{c}5.6 \\
\pm \\
0.3 \\
\end{array}$ & $\begin{array}{c}4.5 \\
\pm \\
0.4 \\
\end{array}$ & $\begin{array}{c}4.7 \\
\pm \\
0.4 \\
\end{array}$ & $\begin{array}{c}6.1 \\
\pm \\
0.3 \\
\end{array}$ & $\begin{array}{c}6.5 \\
\pm \\
0.3 \\
\end{array}$ & $\begin{array}{c}4.8 \\
\pm \\
0.3 \\
\end{array}$ & $\begin{array}{c}5.0 \\
\pm \\
0.3 \\
\end{array}$ & $\begin{array}{c}4.0 \\
\pm \\
0.2 \\
\end{array}$ & $\begin{array}{c}4.2 \\
\pm \\
0.2 \\
\end{array}$ & $\begin{array}{c}5.3 \\
\pm \\
0.3 \\
\end{array}$ & $\begin{array}{c}5.6 \\
\pm \\
0.3 \\
\end{array}$ \\
\hline 5 & $\begin{array}{c}6.1 \\
\pm \\
0.5\end{array}$ & $\begin{array}{c}6.5 \\
\pm \\
0.5\end{array}$ & $\begin{array}{c}5.0 \\
\pm \\
0.3\end{array}$ & $\begin{array}{c}5.3 \\
\pm \\
0.3\end{array}$ & $\begin{array}{c}4.2 \\
\pm \\
0.3\end{array}$ & $\begin{array}{c}4.3 \\
\pm \\
0.3\end{array}$ & $\begin{array}{c}5.1 \\
\pm \\
0.3\end{array}$ & $\begin{array}{c}5.4 \\
\pm \\
0.3\end{array}$ & $\begin{array}{c}4.3 \\
\pm \\
0.4\end{array}$ & $\begin{array}{c}4.5 \\
\pm \\
0.4\end{array}$ & $\begin{array}{c}3.9 \\
\pm \\
0.3\end{array}$ & $\begin{array}{c}4.1 \\
\pm \\
0.3\end{array}$ & $\begin{array}{c}5.3 \\
\pm \\
0.3\end{array}$ & $\begin{array}{c}5.6 \\
\pm \\
0.3\end{array}$ & $\begin{array}{c}3.8 \\
\pm \\
0.2\end{array}$ & $\begin{array}{c}3.9 \\
\pm \\
0.2\end{array}$ & $\begin{array}{c}3.1 \\
\pm \\
0.2\end{array}$ & $\begin{array}{c}3.2 \\
\pm \\
0.2\end{array}$ & $\begin{array}{c}4.1 \\
\pm \\
0.2\end{array}$ & $\begin{array}{c}4.3 \\
\pm \\
0.2\end{array}$ \\
\hline 6 & $\begin{array}{c}5.0 \\
\pm \\
0.4\end{array}$ & $\begin{array}{c}5.3 \\
\pm \\
0.4\end{array}$ & $\begin{array}{c}4.2 \\
\pm \\
0.5\end{array}$ & $\begin{array}{c}4.4 \\
\pm \\
0.5\end{array}$ & $\begin{array}{c}3.5 \\
\pm \\
0.3\end{array}$ & $\begin{array}{c}3.6 \\
\pm \\
0.3\end{array}$ & $\begin{array}{c}4.3 \\
\pm \\
0.4\end{array}$ & $\begin{array}{c}4.5 \\
\pm \\
0.4\end{array}$ & $\begin{array}{c}3.6 \\
\pm \\
0.3\end{array}$ & $\begin{array}{c}3.7 \\
\pm \\
0.3\end{array}$ & $\begin{array}{c}3.1 \\
\pm \\
0.3\end{array}$ & $\begin{array}{c}3.2 \\
\pm \\
0.3\end{array}$ & $\begin{array}{c}4.2 \\
\pm \\
0.4\end{array}$ & $\begin{array}{c}4.4 \\
\pm \\
0.4\end{array}$ & $\begin{array}{c}3.0 \\
\pm \\
0.3\end{array}$ & $\begin{array}{c}3.1 \\
\pm \\
0.3\end{array}$ & $\begin{array}{c}2.9 \\
\pm \\
0.3\end{array}$ & $\begin{array}{c}3.0 \\
\pm \\
0.3\end{array}$ & $\begin{array}{c}3.3 \\
\pm \\
0.2\end{array}$ & $\begin{array}{c}3.5 \\
\pm \\
0.2\end{array}$ \\
\hline 7 & $\begin{array}{c}4.5 \\
\pm \\
0.3\end{array}$ & $\begin{array}{c}4.7 \\
\pm \\
0.3\end{array}$ & $\begin{array}{c}4.0 \\
\pm \\
0.4\end{array}$ & $\begin{array}{c}4.2 \\
\pm \\
0.4\end{array}$ & $\begin{array}{c}3.2 \\
\pm \\
0.3\end{array}$ & $\begin{array}{c}3.3 \\
\pm \\
0.3\end{array}$ & $\begin{array}{c}3.9 \\
\pm \\
0.3\end{array}$ & $\begin{array}{c}4.1 \\
\pm \\
0.3\end{array}$ & $\begin{array}{c}3.4 \\
\pm \\
0.1\end{array}$ & $\begin{array}{c}3.5 \\
\pm \\
0.1\end{array}$ & $\begin{array}{c}2.9 \\
\pm \\
0.2\end{array}$ & $\begin{array}{c}3.0 \\
\pm \\
0.2\end{array}$ & $\begin{array}{c}3.8 \\
\pm \\
0.3\end{array}$ & $\begin{array}{c}4.0 \\
\pm \\
0.3\end{array}$ & $\begin{array}{c}2.7 \\
\pm \\
0.2\end{array}$ & $\begin{array}{c}2.8 \\
\pm \\
0.2\end{array}$ & $\begin{array}{c}2.8 \\
\pm \\
0.1\end{array}$ & $\begin{array}{c}2.9 \\
\pm \\
0.1\end{array}$ & $\begin{array}{c}3.0 \\
\pm \\
0.1\end{array}$ & $\begin{array}{c}3.1 \\
\pm \\
0.1\end{array}$ \\
\hline
\end{tabular}


Table 2. Density of woods

\begin{tabular}{|c|c|c|c|c|c|c|c|c|c|c|}
\hline $\begin{array}{c}\text { Weeks of } \\
\text { Drying }\end{array}$ & $\begin{array}{c}\text { Mango } \\
\left(\mathrm{kg} / \mathrm{m}^{3}\right)\end{array}$ & $\begin{array}{c}\text { Tamarind } \\
\left(\mathrm{kg} / \mathrm{m}^{3}\right)\end{array}$ & $\begin{array}{c}\text { Raintree } \\
\left(\mathrm{kg} / \mathrm{m}^{3}\right)\end{array}$ & $\begin{array}{c}\text { Jamun } \\
\left(\mathrm{kg} / \mathrm{m}^{3}\right)\end{array}$ & $\begin{array}{c}\text { Margosa } \\
\left(\mathrm{kg} / \mathrm{m}^{3}\right)\end{array}$ & $\begin{array}{c}\text { Lemon } \\
\left(\mathrm{kg} / \mathrm{m}^{3}\right)\end{array}$ & $\begin{array}{c}\text { Pine } \\
\left(\mathrm{kg} / \mathrm{m}^{3}\right)\end{array}$ & $\begin{array}{c}\text { Black } \\
\text { Mangrove } \\
\left(\mathrm{kg} / \mathrm{m}^{3}\right)\end{array}$ & $\begin{array}{c}\text { Guava } \\
\left(\mathrm{kg} / \mathrm{m}^{3}\right)\end{array}$ & $\begin{array}{c}\text { Australian } \\
\text { Pine } \\
\left(\mathrm{kg} / \mathrm{m}^{3}\right)\end{array}$ \\
\hline 0 & $1004 \pm 80$ & $969 \pm 60$ & $721 \pm 60$ & $819 \pm 60$ & $1061 \pm 50$ & $1141 \pm 70$ & $1092 \pm 50$ & $1296 \pm 70$ & $1139 \pm 80$ & $1336 \pm 90$ \\
\hline 1 & $732 \pm 70$ & $761 \pm 50$ & $531 \pm 50$ & $627 \pm 70$ & $870 \pm 50$ & $764 \pm 50$ & $768 \pm 50$ & $1003 \pm$ & $941 \pm$ & $1062 \pm 50$ \\
\hline 2 & $628 \pm 70$ & $662 \pm 40$ & $486 \pm 70$ & $550 \pm 50$ & $790 \pm 50$ & $708 \pm 60$ & $669 \pm 60$ & $904 \pm$ & $867 \pm$ & $760 \pm 60$ \\
\hline 3 & $570 \pm 80$ & $606 \pm 50$ & $461 \pm 50$ & $527 \pm 60$ & $740 \pm 80$ & $673 \pm 40$ & $614 \pm 50$ & $853 \pm$ & 825 & $711 \pm 50$ \\
\hline 4 & $531 \pm 60$ & $571 \pm 60$ & $438 \pm 60$ & $456 \pm 40$ & $701 \pm 60$ & $643 \pm 50$ & $576 \pm 30$ & $812 \pm$ & $793 \pm$ & $711 \pm 40$ \\
\hline 5 & $498 \pm 50$ & $542 \pm 80$ & $419 \pm 40$ & $435 \pm 30$ & $671 \pm 70$ & $617 \pm 60$ & $546 \pm 20$ & $781 \pm$ & $768 \pm$ & $682 \pm 50$ \\
\hline 6 & $473 \pm 60$ & $519 \pm 70$ & $405 \pm 50$ & $417 \pm 30$ & $647 \pm 40$ & $598 \pm 50$ & $523 \pm 40$ & $758 \pm$ & $746 \pm$ & $661 \pm 20$ \\
\hline 7 & $452 \pm 40$ & $499 \pm 60$ & $392 \pm 40$ & $401 \pm 20$ & $625 \pm 30$ & $581 \pm 30$ & $503 \pm 50$ & $729 \pm$ & $725 \pm$ & $641 \pm 40$ \\
\hline
\end{tabular}

Table 3. Calorofic Value of woods

\begin{tabular}{|c|c|c|c|c|c|c|c|c|c|c|}
\hline $\begin{array}{c}\text { Weeks of } \\
\text { Drying }\end{array}$ & $\begin{array}{c}\text { Mango } \\
\text { (MJ/kg) }\end{array}$ & $\begin{array}{c}\text { Tamarind } \\
(\mathrm{MJ} / \mathrm{kg})\end{array}$ & $\begin{array}{c}\text { Raintree } \\
(\mathrm{MJ} / \mathrm{kg})\end{array}$ & $\begin{array}{c}\text { Jamun } \\
(\mathrm{MJ} / \mathrm{kg})\end{array}$ & $\begin{array}{c}\text { Margosa } \\
(\mathrm{MJ} / \mathbf{k g})\end{array}$ & $\begin{array}{c}\text { Lemon } \\
(\mathrm{MJ} / \mathrm{kg})\end{array}$ & $\begin{array}{c}\text { Pine } \\
(\mathrm{MJ} / \mathrm{kg})\end{array}$ & $\begin{array}{c}\text { Black } \\
\text { Mangrove } \\
(\mathrm{MJ} / \mathrm{kg}) \\
\end{array}$ & $\begin{array}{c}\text { Guava } \\
\text { (MJ/kg) }\end{array}$ & $\begin{array}{c}\text { Australian } \\
\text { Pine } \\
\text { (MJ/kg) } \\
\end{array}$ \\
\hline 0 & $14 \pm 4$ & $10 \pm 3$ & $9 \pm 3$ & $8 \pm 3$ & $10 \pm 3$ & $16 \pm 4$ & $17 \pm 4$ & $17 \pm 4$ & $15 \pm 3$ & $18 \pm 4$ \\
\hline 1 & $20 \pm 3$ & $18 \pm 4$ & $16 \pm 4$ & $14 \pm 4$ & $19 \pm 4$ & $24 \pm 3$ & $21 \pm 4$ & $23 \pm 5$ & $21 \pm 5$ & $26 \pm 3$ \\
\hline 2 & $24 \pm 3$ & $20 \pm 4$ & $18 \pm 5$ & $18 \pm 4$ & $22 \pm 3$ & $27 \pm 4$ & $23 \pm 3$ & $26 \pm 4$ & $24 \pm 4$ & $31 \pm 4$ \\
\hline 3 & $24 \pm 4$ & $22 \pm 3$ & $20 \pm 3$ & $20 \pm 4$ & $23 \pm 5$ & $28 \pm 4$ & $24 \pm 5$ & $28 \pm 6$ & $26 \pm 5$ & $32 \pm 6$ \\
\hline 4 & $25 \pm 6$ & $23 \pm 5$ & $21 \pm 5$ & $23 \pm 3$ & $24 \pm 6$ & $30 \pm 5$ & $26 \pm 5$ & $29 \pm 5$ & $27 \pm 5$ & $32 \pm 5$ \\
\hline 5 & $26 \pm 6$ & $23 \pm 7$ & $22 \pm 6$ & $24 \pm 4$ & $24 \pm 5$ & $31 \pm 6$ & $27 \pm 6$ & $30 \pm 5$ & $28 \pm 5$ & $33 \pm 6$ \\
\hline 6 & $26 \pm 6$ & $24 \pm 5$ & $23 \pm 7$ & $24 \pm 6$ & $25 \pm 6$ & $32 \pm 7$ & $27 \pm 5$ & $31 \pm 4$ & $29 \pm 6$ & $34 \pm 5$ \\
\hline 7 & $26 \pm 7$ & $24 \pm 6$ & $23 \pm 7$ & $24 \pm 5$ & $26 \pm 6$ & $32 \pm 8$ & $29 \pm 7$ & $31 \pm 5$ & $30 \pm 7$ & $36 \pm 8$ \\
\hline
\end{tabular}

One noteworthy condition to notice is that densities of Pine, Raintree and other softwoods such as Jamun and Mango decrease the most with decreasing moisture content. This can be attributed to the fact that unlike Australian Pine, Guava, Margosa, Lemon and Black Mangrove which are hardwoods, Pine, Raintree, Jamun and Mango are softwoods and thus have loosely packed cells [9] as a result water is able to evaporate quite easily. Hardwoods have tightly packed cells and rate of moisture loss is less compared to softwoods.

Figure 7 illustrates that a decreasing calorific value is observed with increasing density. Fresh wood always consists of moisture in its structure and the high density is the result of this. Therefore, there is a lower combustible substance per weight of fuel as a result there is a reduction in calorific value [10].

It was noted that drier woods produced cleaner flames and stove efficiencies were higher for these woods. The efficiency of the stove, $\eta$, is defined as the heat gained by the water and the pot divided by the heat supplied by the burning fuel. This heat supplied by the fuel was assumed to be the energy content of the respective fuel (its calorific value) given the fuel completely burns off without residue. Figure 8 reveals that Margosa reached the highest stove efficiency of around $12 \%$.

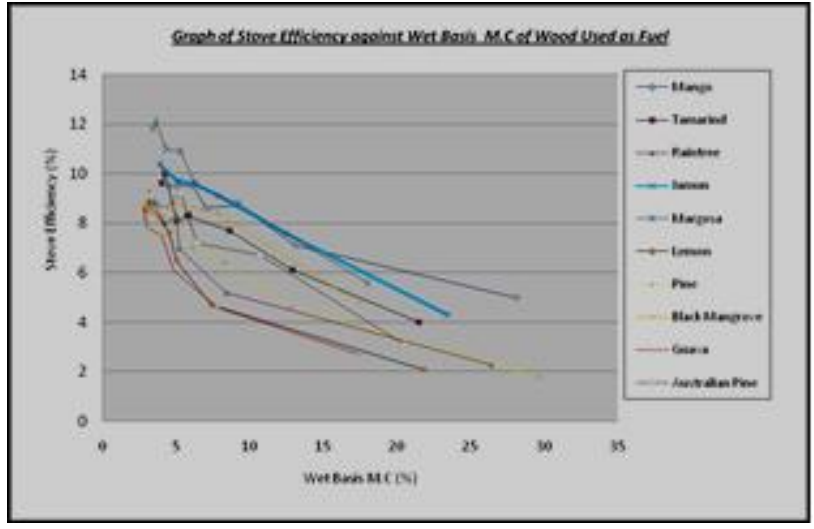

Figure 8. Stove Efficiencies against Wet Basis M.C

\section{Conclusions}

Efficiency of the fuelwood was found to be inversely related to the fuelwood's moisture content. Hardwoods have higher efficiencies compared to the softwoods. This is probably due to the fact that hardwoods have compact cellular structures resulting in longer burning times which 
ensured that a constant level of energy is sustained to the water and its vessel. The next best efficient fuelwood is Australian Pine with efficiencies of around 11\% at 5\% moisture contents. Pine, Raintree and Jamun displayed poor burning capabilities. Since efficiency of the fuelwood is also dependent on the calorific values.

\section{Acknowledgements}

We are very grateful to experts for their appropriate and constructive suggestions to improve the above research namely Dr. Anirudh Singh, Dr. Kifle Kahsai, Mr. Radesh Lal, and Mr. Som Sundaram Mudiliar of Nawai settlement for his assistance in gathering the wood samples used in this project.

\section{REFERENCES}

[1] Fiji Bureau of Statistics, Online Available from http://www.statsfiji.gov.fj/

[2] REN 21, Renewables 2014 Global Status Report, Online
Available from

https://www.google.com.fj/?gws_rd=ssl\#q=ren21+2 014

[3] Kumar M and K Mala, PH301-Energy Supplies Laboratory Manual, The University of the South Pacific, Suva, Fiji, 2004.

[4] J. Hartley, J. Marchant. Methods of Determining the Moisture Content of Wood, Research Division, State Forest of New South Wales, Sydney, 1995.

[5] Wood Fuels Handbook, Online Available from http://www.biomass trade centres.eu

[6] Ryan P A, Forage Tree Legumes in Tropical Agriculture, Online Available from http;//www.fao.org

[7] M. Huhtinen , Wood Biomass as a Fuel, Online Available from http://www.ncp.fi/.../WoodProperties.html

[8] J.A Fuwape, A.Cand. Biomass Yield and Energy Values of some fast-growing multipurpose trees in Nigeria, Journal of Biomass and Bioenergy, Vol.10, No.5, $101-106$.

[9] R. Kataki, D. Konwer. Fuelwood Characteristics of some indigenous woody species of North-East India, Journal of Biomass and Bioenergy, Vol.20, 17-23.

[10] J.J. Jatter, P. Kariher. Solid-Fuel household cook Stoves; characterization of performance and emissions, Journal of Biomass and Bioenergy, Vol.33, No.2, 294-300. 